\title{
Genetic and Phenotypic Analysis of Soybean mosaic virus Resistance in PI 88788 Soybean
}

\author{
Irfan Gunduz, Glenn R. Buss, Pengyin Chen, and Sue A. Tolin
}

First, second, and third authors: Department of Crop and Soil Environmental Sciences, Virginia Polytechnic Institute and State University, Blacksburg 24061; and fourth author: Department of Plant Pathology, Physiology, and Weed Science, Virginia Polytechnic Institute and State University, Blacksburg 24061.

Current address of P. Chen: Department of Crop, Soil, and Environmental Sciences, University of Arkansas, Fayetteville 72701.

Accepted for publication 20 January 2004.

\begin{abstract}
Gunduz, I., Buss, G. R., Chen, P., and Tolin, S. A. 2004. Genetic and phenotypic analysis of Soybean mosaic virus resistance in PI 88788 soybean. Phytopathology 94:687-692.

Resistance to Soybean mosaic virus (SMV) was identified in PI 88788 soybean, a germ plasm accession from China that is used widely as a source of resistance to soybean cyst nematode. Strains SMV-G1 through -G7 infected the inoculated leaves of PI 88788 but were not detected in upper, noninoculated trifoliolate leaves. Inheritance of resistance was determined by inoculating progenies of crosses of PI 88788 with susceptible cvs.

$R s v 1, R s v 3$, and Rsv4 genes, respectively. Data analyses showed that resistance in PI 88788 to SMV-G1 is controlled by a single, partially dominant gene; however, to SMV-G7, the same gene was completely dominant. The PI 88788 gene was independent of the Rsv1 and Rsv3 loci, but allelic to Rsv4 in V94-5152. Expression of the Rsv4 gene in PI 88788 resulted in a reduced number of infection sites and restricted short- and long-distance movement of virus, rather than hypersensitivity. A unique late susceptible phenotype was strongly associated with heterozygosity. This gene has potential value for use in gene pyramiding to achieve resistance to several SMV strains, as well as for rate-reducing resistance.
\end{abstract} Essex and Lee 68 with SMV strains G1 and G7. Allelomorphic relationships with known genes for resistance to SMV were tested in crosses with the resistant genotypes PI 96983, L29, and V94-5152, possessing
Additional keywords: broad resistance, Glycine max, late susceptibility, partial dominance.
Soybean mosaic virus (SMV; genus Potyvirus, family Potyviridae) is one of the most common viral diseases of soybean (Glycine max (L.) Merr.) and can cause severe yield losses (13, 21). Controlling crop losses depends on utilization of resistant cultivars because no other effective way of managing the disease currently is available. To date, three SMV-resistant loci, Rsv1, $R s v 3$, and $R s v 4$, have been named. Resistance genes at these loci confer differential reactions to SMV strains G1 through G7 as defined by Cho and Goodman (14,15). A single dominant gene for SMV resistance was identified in PI 96983 and designated as $R s v$ (later renamed as $R s v 1)(9,18)$. $R s v l$ has been mapped to soybean molecular linkage group "F" in a cluster of resistance $(R)$ genes $(36,37)$. The symbol $R s v 2$ previously was assigned to the gene in OX670, which presumably was derived from Raiden (6). However, we have shown that OX670 carries two genes; one is derived from Raiden and is allelic to the Rsvl locus while the other is derived from Harosoy and allelic to the Rsv3 locus (17). A unique $R s v 2$ locus does not appear to exist in OX670 or its ancestors; thus, the gene symbol Rsvl-r was assigned to the SMV $R$ gene in Raiden (11). A single dominant gene derived from Columbia and conditioning systemic necrosis to SMV-G1 and -G4 was found to be independent of $R s v 1$ and was designated as $R s v 3$ (7). $R s v 3$ has been mapped to molecular linkage group "B2" (23). L29, an isoline of Williams with SMV resistance derived from Hardee, also has been shown to contain $R s v 3$ (5). A new resistance gene independent of Rsvl and Rsv3 has been reported in PI 486355 (24). This new gene, labeled Rsv4 (20), was isolated in V94-5152,

Corresponding author: S. A. Tolin; E-mail address: stolin@vt.edu

Publication no. P-2004-0427-01R

(c) 2004 The American Phytopathological Society a selection from PI $486355 \times$ 'Essex' (24), and registered as germ plasm (4). The Rsv4 locus has been mapped to soybean molecular linkage group "D1b", a region of the genome with no other mapped resistance genes (20). Columbia also has been found to carry a resistance gene at an independent locus, R4, which conditions early seedling resistance to SMV-G1 and -G7 and delayed systemic, or late-susceptible, symptoms (25).

Many of the SMV resistance genes discovered to date are at the $R s v 1$ locus. However, several of them are alleles at this locus and exhibit resistance to lower-numbered strains of SMV, but either susceptibility or necrosis to higher-numbered strains $(9,11,14)$. On the other hand, alleles at the Rsv3 locus show a susceptible reaction to lower-numbered strains but a resistant reaction to higher-numbered strains (Table 1). PI 88788, an early soybean introduction from China, has been used widely as a source of soybean cyst nematode resistance. Two dominant genes and one recessive gene condition resistance to soybean cyst nematode in PI 88788 (29). We have recognized that it is also resistant to SMV, but the inheritance of resistance to SMV in PI 88788 has not been studied. The objective of this study was to determine (i) the reaction of PI 88788 to SMV strains G1 through G7, (ii) the inheritance of resistance to SMV in PI 88788, and (iii) the allelomorphic relationship of the resistance gene or genes in PI 88788 with previously identified resistance genes. We also demonstrate that the mechanism of action of this dominant gene is to reduce viral infection and accumulation and delay both local and vascular movement. A unique late-susceptible phenotype is described and is strongly associated with certain heterozygotes.

\section{MATERIALS AND METHODS}

The response of PI 88788 to SMV strains G1 through G7 was tested, but only two strains, SMV-G1 and SMV-G7, were used to 
screen $F_{1}$ plants, $F_{2}$ populations, and $F_{2: 3}$ families. These two strains induce differential responses in parental genotypes PI 96983 and L29, carrying Rsv1 and Rsv3, respectively (Table 1). The sources of the virus strains, maintenance of the virus cultures, inoculation procedures, greenhouse conditions, and field plot techniques were as described previously (9).

PI 88788 was crossed with SMV-susceptible cvs. Lee 68 and Essex to study the inheritance of resistance. It also was crossed with resistant lines PI 96983 and L29, which contain Rsv1 and $R s v 3$, respectively, as well as with V94-5152, which contains Rsv4 (4,5,20,23). 'Peking', a plant introduction from China resistant to SMV (G. R. Buss, unpublished data) and carrying a recessive gene for resistance to Peanut mottle virus (32), also was crossed with PI 88788. Crosses were made either in the greenhouse or in the field at Blacksburg, VA. Crosses were distinguished from selfs in the $F_{1}$ and $F_{2}$ generation using leaf shape, seed color, flower color, pubescence color, and maturity as markers.

$F_{1}$ plants were grown in the greenhouse or in the field without SMV inoculation at Blacksburg, VA and harvested individually. $\mathrm{F}_{2}$ plants were grown in the field without virus inoculation at either Blacksburg or Warsaw, VA and were harvested individually to obtain $F_{2: 3}$ families. Remnant $F_{1}$ seed, $F_{2}$ populations, and $F_{2: 3}$ families were tested with SMV-G1 in the greenhouse and field and with SMV-G7 in the greenhouse at Blacksburg, VA. An average of $5 \mathrm{~F}_{1}$ plants, $200 \mathrm{~F}_{2}$ plants per population, and $20 \mathrm{~F}_{2: 3}$ plants from each of $50 \mathrm{~F}_{2: 3}$ families per cross were inoculated. Individual plant reactions were examined at 10, 20, 30, and 40 days postinoculation (dpi) and classified into four distinct phenotypes: resistant (R) (symptomless or with only local necrotic lesions on inoculated leaves), necrotic $(\mathrm{N})$ (local and systemic necrosis that developed into stem tip necrosis and often plant death 10 to 15 dpi), susceptible (S) (mosaic, first trifoliolate showing vein clearing by $7 \mathrm{dpi}$, that developed into mosaic on all leaves), and late-susceptible (LS) (no symptoms until 14 to $21 \mathrm{dpi}$, then transitory chlorotic islands or rings appeared on trifoliolate leaflets). Plants showing systemic necrosis or late susceptibility in $\mathrm{F}_{2}$ populations and $\mathrm{F}_{2: 3}$ progenies were combined with resistant plants for testing fits to standard Mendelian ratios (10). The rationale for combining these phenotypes into the resistant genotype is based on our previous genetic analyses of the segregation of resistance at the Rsv1 locus $(9,10)$ and the R3 and R4 (later called Rsv3 and Rsv4) loci $(17,24,25)$.

To confirm that the LS phenotype was a heritable trait, $200 \mathrm{~F}_{2}$ plants from PI $88788 \times$ Essex and PI $88788 \times$ Lee 68 were planted in the virus nursery at Blacksburg, VA, and inoculated with SMV-G1. Susceptible, late-susceptible, and resistant plants were tagged and harvested to obtain $\mathrm{F}_{2: 3}$ families, which then were planted in the greenhouse and inoculated with SMV-G1. Then, $\chi^{2}$ tests were performed to determine the goodness-of-fit of the observed segregation to expected genetic ratios.

All plants with questionable symptoms, as well as 10 to 20 randomly selected susceptible, symptomless, and necrotic plants, were tested to confirm the presence or absence of SMV by tissueblot immunoassays on nitrocellulose membranes (33). Invasion of inoculated leaves by SMV-G1 and -G7 was tracked by leaf print immunoassays of randomly selected leaves. Briefly, this was done by imprinting leaves onto hardened filter paper (S\&S 410 Filter Paper; Schleicher and Schuell, Keene, NH) (16), decolorizing with Triton X-100, and treating with polyclonal antibody to purified SMV, alkaline phosphatase-conjugated goat anti-rabbit immunoglobulin G (Sigma-Aldrich, St. Louis), and the substrate 5bromo-4-chloro-3-indolyl phosphate and nitro tetrazolium salt (NBT/BCIP) (Zymed Laboratories, Inc., San Francisco).

\section{RESULTS}

Host phenotypic reactions. Susceptible cvs. Essex and Lee 68 exhibited typical veinal clearing in first trifoliolate leaves 6 to $8 \mathrm{dpi}$ and misshapen and puckered trifoliolate leaves 15 to $35 \mathrm{dpi}$, typical of SMV symptoms (Fig. 1A and B). Leaf print immunoassay of SMV-G1-inoculated Essex unifoliolate leaves revealed 20 to 30 infection foci by $9 \mathrm{dpi}$ and complete invasion of the inoculated leaf at a 23-dpi assay time (Fig. 2A and D). In contrast, PI 88788 exhibited no visible symptoms on unifoliolate leaves inoculated with SMV strains G1 through G7 or on any other leaves (Table 1). Only a few foci of infection could be detected by leaf print immunoassay of unifoliolate leaves inoculated with SMV strains G1 (Fig. 2B and E) and G7 (Fig. 2C and F). The area invaded by either G1 or G7 was barely detectable $\left(<1 \mathrm{~mm}^{2}\right)$ at 9 dpi (Fig. 2B and C) and enlarged to 2 to $3 \mathrm{~mm}^{2}$ by $23 \mathrm{dpi}$ (Fig. 2E and F). Leaves of PI 88788 sampled up to 42 dpi showed little increase in area invaded by the virus (data not shown). Neither macroscopically visible symptoms nor virus were detected on the upper leaves in the later growth stages.

The $\mathrm{F}_{1}$ plants from the PI $88788 \mathrm{R} \times \mathrm{S}$ crosses inoculated with G1 exhibited the LS phenotype (Table 2). The $F_{1}$ plants of PI $88788 \times$ Essex exhibited mosaic symptoms, but not until 19 dpi. Later, predominant symptoms were chlorotic vein banding and chlorotic rings, forming green islands (Fig. 1C). Symptoms did not appear on PI $88788 \times$ Lee $68 \mathrm{~F}_{1}$ plants until 35 dpi, suggesting that the susceptible parent influences the susceptibility of the heterozygote. Several $F_{1}$ plants from the PI $88788 \times$ Lee 68 cross also exhibited the LS phenotype upon inoculation with SMV strains G2, G3, G5, or G6 (data not shown). Symptoms developed by 14 dpi with G6, by 26 dpi with G5, and not until 35 dpi with G2 and G3. No symptoms developed following inoculation of either heterozygote with G7.

Inheritance of resistance to SMV-G1 and -G7 in PI 88788. The $\mathrm{F}_{2}$ populations of PI $88788 \times$ Essex and PI $88788 \times$ Lee 68 segregated to fit a 3:1 R:S ratio based on the initial reaction to SMV-G1 at 7 to 10 dpi (data not shown). However, at 20 dpi, LS plants were observed in the $\mathrm{F}_{2}$ populations from PI $88788 \times$ Essex and PI $88788 \times$ Lee 68 . The number of LS plants increased in the 30- and 40-dpi readings. The segregation pattern, based on the 40-dpi reading of the PI $88788(\mathrm{R}) \times$ Essex $(\mathrm{S}) \mathrm{F}_{2}$ population, was consistent with a 1:2:1 R:LS:S ratio (Table 2). The same population planted and inoculated in the field, as well as the PI $88788 \times$ Lee 68 , did not segregate in this ratio but did fit a $3: 1 \mathrm{R}+\mathrm{LS}: \mathrm{S}$ ratio.

Seed from eight randomly selected $\mathrm{F}_{2}$ plants of PI $88788 \times$ Essex, growing in the field and showing LS symptoms, were planted in the greenhouse and inoculated with SMV-G1. Segregation in

TABLE 1. Reaction of parental soybean genotypes to seven Soybean mosaic virus (SMV) strain groups

\begin{tabular}{|c|c|c|c|c|c|c|c|}
\hline \multirow[b]{2}{*}{ Parents (genotype) } & \multicolumn{7}{|c|}{ SMV strains ${ }^{\mathrm{a}}$} \\
\hline & G1 & $\mathrm{G} 2$ & G3 & G4 & G5 & G6 & G7 \\
\hline Essex (rsv) & $S$ & $\mathrm{~S}$ & $S$ & $\mathrm{~S}$ & $\mathrm{~S}$ & $\mathrm{~S}$ & $\mathrm{~S}$ \\
\hline Lee 68 (rsv) & $\mathrm{S}$ & $\mathrm{S}$ & $\mathrm{S}$ & $\mathrm{S}$ & $\mathrm{S}$ & $\mathrm{S}$ & $\mathrm{S}$ \\
\hline PI $96983(R s v 1)$ & $\mathrm{R}$ & $\mathrm{R}$ & $\mathrm{R}$ & $\mathrm{R}$ & $\mathrm{R}$ & $\mathrm{R}$ & $\mathrm{N}$ \\
\hline L29 $(R s v 3)$ & $\mathrm{S}$ & $\mathrm{S}$ & $\mathrm{S}$ & $\mathrm{S}$ & $\mathrm{R}$ & $\mathrm{R}$ & $\mathrm{R}$ \\
\hline V94-5152(Rsv4) & $\mathrm{R}$ & $\mathrm{R}$ & $\mathrm{R}$ & $\mathrm{R}$ & $\mathrm{R}$ & $\mathrm{R}$ & $\mathrm{R}$ \\
\hline PI 88788 & $\mathrm{R}$ & $\mathrm{R}$ & $\mathrm{R}$ & $\mathrm{R}$ & $\mathrm{R}$ & $\mathrm{R}$ & $\mathrm{R}$ \\
\hline
\end{tabular}

${ }^{a} \mathrm{R}$, resistant (symptomless); N, necrotic (systemic necrosis); S, susceptible (mosaic). 

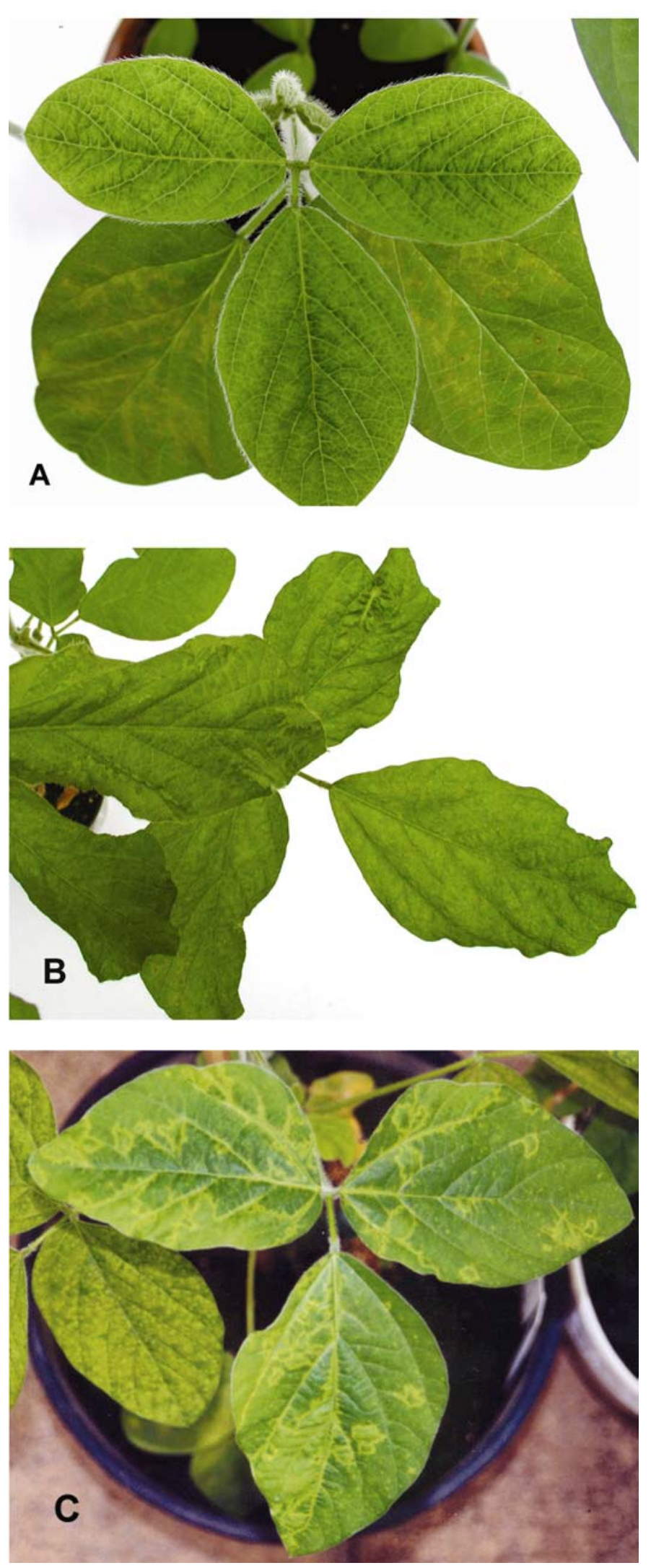

Fig. 1. Symptoms on soybean in the greenhouse at various days postinoculation (dpi) with Soybean mosaic virus strain G1. A, Unifoliolate and first trifoliolate leaves of 'Essex' (susceptible) at $7 \mathrm{dpi}$, showing local chlorotic lesions and vein clearing. B, Upper trifoliolate leaves of Essex at $35 \mathrm{dpi}$, showing mosaic and leaf curl symptoms. C, Upper trifoliolate leaves of heterozygous $F_{1}$ plants of PI 88788 (resistant) $\times$ Essex at $32 \mathrm{dpi}$, showing the partial resistance response of chlorotic vein banding and green islands. the eight LS $\mathrm{F}_{2: 3}$ families of PI $88788 \times$ Essex was consistent and homogeneous with a $3: 1 \mathrm{R}: \mathrm{S}$ ratio at $9 \mathrm{dpi}$ and $1: 2: 1 \mathrm{R}: \mathrm{LS}: \mathrm{S}$ ratio at $41 \mathrm{dpi}$ (Table 3).

Inoculation with SMV-G7 did not induce symptoms on $\mathrm{F}_{1}$ plants of PI $88788 \times$ Essex and PI $88788 \times$ Lee 68 (Table 2). $F_{2}$ populations of the same crosses segregated in a $3: 1 \mathrm{R}: \mathrm{S}$ ratio (Table 2). $\mathrm{F}_{2: 3}$ families of PI $88788 \times$ Lee 68 and PI $88788 \times$ Essex segregated in a 1:2:1 (all R:[3(R+LS):1S]:all S) phenotypic ratio when inoculated with SMV-G1 (Table 4). The $F_{2: 3}$ population of PI $88788 \times$ Essex segregated to fit a 1:2:1 (all R:[3R:1S]:all S) phenotypic ratio when inoculated with G7 (Table 4). All $\mathrm{F}_{2: 3}$ lines from PI $88788 \times$ Essex exhibited the same reaction to both strains, except that LS plants were observed in the segregating lines inoculated with SMV-G1 but not with SMV-G7 (Tables 2 and 4).

Allelic relationship of the resistance gene in PI 88788 with $\boldsymbol{R s v 1 ,} \boldsymbol{R} \boldsymbol{s v} 3$, and $\boldsymbol{R} \boldsymbol{s} \boldsymbol{4}$. The $\mathrm{F}_{2}$ population from PI $88788(\mathrm{R}) \times \mathrm{PI}$ 96983 (R, Rsvl) segregated to fit a digenic ratio of $15: 1$ $\mathrm{R}+\mathrm{LS}+\mathrm{N}: \mathrm{S}$ when inoculated with SMV-G1 (Table 2). $\mathrm{F}_{2: 3}$ lines from the same cross exhibited a segregation ratio of 7:4:4:1 (all $\mathrm{R}:[15(\mathrm{R}+\mathrm{LS}+\mathrm{N}): 1 \mathrm{~S}]:[(3(\mathrm{R}+\mathrm{N}+\mathrm{LS}): 1 \mathrm{~S}]:$ all S) (Table 5). Segregation in the $\mathrm{F}_{2}$ population from L29 $(\mathrm{R}, R s v 3) \times \mathrm{PI} 88788(\mathrm{R})$ was consistent with a digenic ratio of $15: 1 \mathrm{R}: \mathrm{S}$ when inoculated with SMV-G7 (Table 2). $\mathrm{F}_{2: 3}$ families from the same cross showed a 7:4:4:1 (all R:[15R:1S]:[3R:1S]:all S) segregation ratio (Table 6). There were no susceptible plants identified in the $\mathrm{F}_{2}$ and $\mathrm{F}_{2: 3}$ populations from V94-5152 (R, Rsv4) × PI $88788(\mathrm{R})$ when inoculated with SMV-G1 (Tables 2 and 4). Progeny of crosses between Peking and PI 88788 also were all resistant (data not shown).

\section{DISCUSSION}

It is very clear from our data that the resistance gene in PI 88788 is independent of $R s v 1$ and Rsv3. The data suggest that the single, dominant resistance gene in PI 88788 is allelic to the SMV resistance gene at the $R s v 4$ locus in V94-5152. No phenotypic differences were observed in the expression of the two sources of $R s v 4$; therefore, it is likely that they are the same allele. The gene carried by Peking also appears to be at the Rsv4 locus.

Rsv4 homozygotes (Fig. 2) and heterozygotes (data not shown) show a reduced number of initial virus infection sites compared with the Essex (rsv4) and Lee 68 (rsv4) parents, with both SMV strains G1 and G7. Vascular movement of SMV-G1 in homozy-

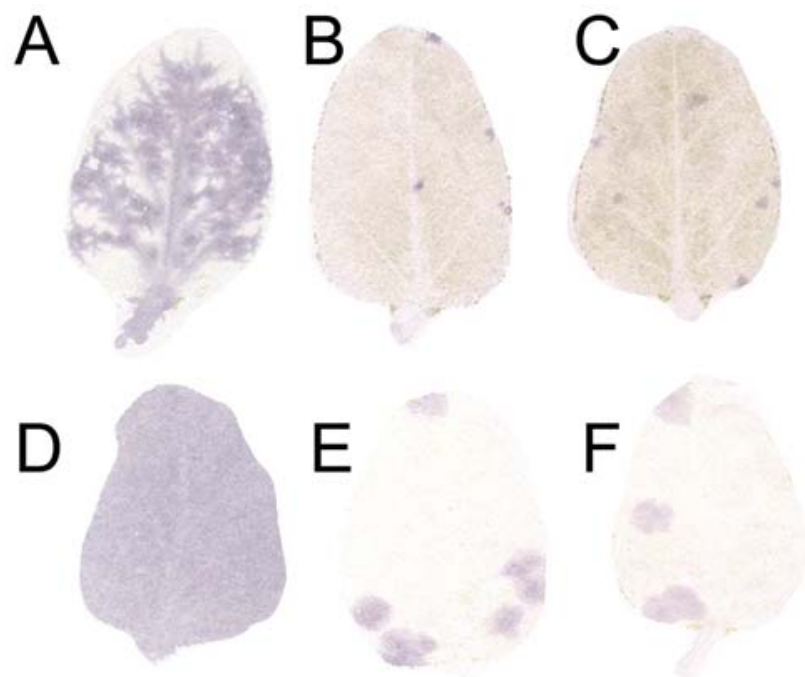

Fig. 2. Leaf print immunoassays of inoculated leaves of $\mathbf{A}$ and D, Essex and $\mathbf{B}, \mathbf{C}, \mathbf{E}$, and F, PI 88788 at $\mathbf{A}$ to $\mathbf{C ,}, 9$ and $\mathbf{D}$ to $\mathbf{F}, 23$ days postinoculation with A, B, D, and E, Soybean mosaic virus (SMV) strain G1 or C and F, SMV-G7. Dark blue areas indicate presence of viral antigen. 
gotes is severely restricted, but in heterozygotes it was merely delayed, indicating that the gene expresses partial dominance in response to SMV-G1. The delayed vascular movement resulted in symptoms referred to here as late susceptible (LS), and was typified by $\mathrm{F}_{1}$ plants (heterozygote) of PI $88788(\mathrm{R}) \times$ Essex $(\mathrm{S})$ upon inoculation with SMV-G1. LS plants also were consistently observed in segregating populations of PI $88788(\mathrm{R}) \times \operatorname{Essex}(\mathrm{S})$ and
PI $88788(\mathrm{R}) \times$ Lee $68(\mathrm{~S})$. Moreover, all $\mathrm{F}_{2: 3}$ families derived from LS $\mathrm{F}_{2}$ plants segregated for R, LS, and $\mathrm{S}$ phenotypes, and LS plants always were observed in segregating $\mathrm{F}_{2: 3}$ progenies derived from $\mathrm{R} \times \mathrm{S}$ crosses. These observations suggest a strong association between heterozygosity and late susceptibility.

The association between late susceptibility and heterozygosity was not as strong in populations tested in the field, as seen in the

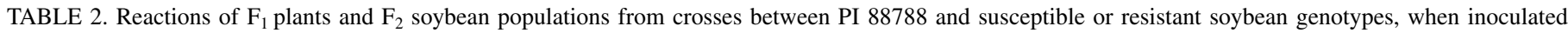
with Soybean mosaic virus (SMV) strains G1 and G7

\begin{tabular}{|c|c|c|c|c|c|c|c|c|}
\hline \multirow[b]{2}{*}{ Cross, generation } & \multirow[b]{2}{*}{ SMV strain } & \multicolumn{4}{|c|}{ Number of plants ${ }^{\mathrm{a}}$} & \multirow[b]{2}{*}{ Expected ratio } & \multirow[b]{2}{*}{$\chi^{2}$} & \multirow[b]{2}{*}{$P$} \\
\hline & & $\mathrm{R}$ & $\mathrm{N}$ & $\mathrm{LS}$ & $\mathrm{S}$ & & & \\
\hline PI $88788(\mathrm{R}) \times \operatorname{Essex}(\mathrm{S}) \mathrm{F}_{1}$ & G1 & 0 & 0 & 10 & 0 & $\ldots$ & $\ldots$ & $\ldots$ \\
\hline PI $88788(\mathrm{R}) \times$ Essex $(\mathrm{S}) \mathrm{F}_{2}$ & G1 & 86 & 0 & 151 & 67 & 1R:2LS:1S & 2.39 & 0.30 \\
\hline PI $88788(\mathrm{R}) \times \operatorname{Essex}(\mathrm{S}) \mathrm{F}_{2}{ }^{\mathrm{b}}$ & G1 & 41 & 0 & 24 & 16 & $3(\mathrm{R}+\mathrm{LS}): 1 \mathrm{~S}$ & 1.19 & 0.27 \\
\hline PI $88788(\mathrm{R}) \times \operatorname{Essex}(\mathrm{S}) \mathrm{F}_{1}$ & G7 & 4 & 0 & 0 & 0 & & & \\
\hline PI $88788(\mathrm{R}) \times$ Essex $(\mathrm{S}) \mathrm{F}_{2}$ & G7 & 210 & 0 & 0 & 56 & 3R:1S & 2.21 & 0.14 \\
\hline PI $88788(\mathrm{R}) \times$ Lee $68(\mathrm{~S}) \mathrm{F}_{1}$ & G1 & 0 & 0 & 7 & 0 & & & \\
\hline PI $88788(\mathrm{R}) \times$ Lee $68(\mathrm{~S}) \mathrm{F}_{2}$ & G1 & 90 & 0 & 45 & 35 & $3(\mathrm{R}+\mathrm{LS}): 1 \mathrm{~S}$ & 1.76 & 0.18 \\
\hline PI $88788(\mathrm{R}) \times$ Lee $68(\mathrm{~S}) \mathrm{F}_{2}{ }^{\mathrm{b}}$ & G1 & 55 & 0 & 16 & 22 & $3(\mathrm{R}+\mathrm{LS}): 1 \mathrm{~S}$ & 0.09 & 0.76 \\
\hline PI $88788(\mathrm{R}) \times$ Lee $68(\mathrm{~S}) \mathrm{F}_{1}$ & G7 & 4 & 0 & 0 & 0 & & & \\
\hline PI $88788(\mathrm{R}) \times$ Lee $68(\mathrm{~S}) \mathrm{F}_{2}$ & G7 & 156 & 0 & 0 & 45 & 3R:1S & 0.73 & 0.39 \\
\hline PI $88788(\mathrm{R}) \times$ PI $96983(R s v 1) \mathrm{F}_{2}$ & G1 & 262 & 4 & 36 & 26 & $15(\mathrm{R}+\mathrm{N}+\mathrm{LS}): 1 \mathrm{~S}$ & 1.57 & 0.21 \\
\hline $\mathrm{L} 29(R s v 3) \times \mathrm{PI} 88788(\mathrm{R}) \mathrm{F}_{2}$ & G7 & 272 & 0 & 0 & 25 & 15R:1S & 2.38 & 0.12 \\
\hline V94-5152 $(R s v 4) \times$ PI $88788(\mathrm{R}) \mathrm{F}_{2}$ & G1 & 325 & 0 & 0 & 0 & $\ldots$ & $\ldots$ & $\ldots$ \\
\hline
\end{tabular}

${ }^{a} \mathrm{R}$, resistant (symptomless); $\mathrm{S}$, susceptible (mosaic); LS, late susceptible; N, necrotic.

b Data taken from field.

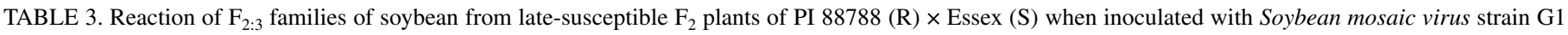
in the greenhouse ${ }^{\mathrm{a}}$

\begin{tabular}{|c|c|c|c|c|c|c|c|c|c|c|c|c|}
\hline \multirow[b]{2}{*}{$\mathrm{F}_{2: 3}$ family } & \multirow[b]{2}{*}{ No. of plants } & \multicolumn{5}{|c|}{9 dpi } & \multicolumn{6}{|c|}{$41 \mathrm{dpi}$} \\
\hline & & $\mathrm{R}$ & $\mathrm{S}$ & $\chi_{3: 1}^{2}$ & $\mathrm{df}$ & $P$ & $\mathrm{R}$ & LS & $\mathrm{S}$ & $\chi_{1: 2: 1}^{2}$ & df & $P$ \\
\hline 1 & 15 & 14 & 1 & 2.69 & 1 & 0.10 & 4 & 10 & 1 & 2.87 & 2 & 0.24 \\
\hline 2 & 11 & 7 & 4 & 0.76 & 1 & 0.39 & 0 & 7 & 4 & 3.73 & 2 & 0.15 \\
\hline 3 & 14 & 10 & 4 & 0.09 & 1 & 0.77 & 3 & 7 & 4 & 0.14 & 2 & 0.93 \\
\hline 4 & 17 & 14 & 3 & 0.49 & 1 & 0.48 & 4 & 10 & 3 & 0.65 & 2 & 0.73 \\
\hline 5 & 16 & 13 & 3 & 0.33 & 1 & 0.57 & 2 & 11 & 3 & 2.37 & 2 & 0.31 \\
\hline 6 & 15 & 11 & 4 & 0.02 & 1 & 0.89 & 2 & 9 & 4 & 1.13 & 2 & 0.57 \\
\hline 7 & 16 & 10 & 6 & 1.33 & 1 & 0.25 & 6 & 4 & 6 & 4.00 & 2 & 0.14 \\
\hline 8 & 13 & 9 & 4 & 0.23 & 1 & 0.63 & 4 & 5 & 4 & 0.69 & 2 & 0.71 \\
\hline Total & 117 & $\ldots$ & $\ldots$ & 5.920 & 8 & $\ldots$ & $\ldots$ & $\ldots$ & $\ldots$ & 15.65 & 16 & $\ldots$ \\
\hline Pooled & $\ldots$ & 88 & 29 & 0.003 & 1 & 0.96 & 25 & 63 & 29 & 0.97 & 2 & 0.62 \\
\hline Heterogeneity & $\ldots$ & $\ldots$ & $\ldots$ & 5.917 & 7 & 0.55 & $\ldots$ & $\ldots$ & $\ldots$ & 14.6 & 14 & 0.41 \\
\hline
\end{tabular}

a dpi, days postinoculation; R, resistant (symptomless); LS, late susceptible; S, susceptible; df, degrees of freedom.

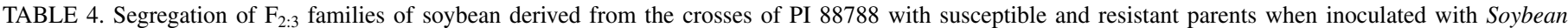
mosaic virus (SMV) strains G1 and G7 in the greenhouse

\begin{tabular}{|c|c|c|c|c|c|c|c|}
\hline \multirow[b]{2}{*}{ Cross, parents } & \multirow[b]{2}{*}{ SMV strain } & \multicolumn{3}{|c|}{ Number of families ${ }^{a}$} & \multirow[b]{2}{*}{ Expected ratio } & \multirow[b]{2}{*}{$\chi^{2}$} & \multirow[b]{2}{*}{$P$} \\
\hline & & All R & $\mathrm{H}$ & All S & & & \\
\hline PI $88788(\mathrm{R}) \times \operatorname{Essex}(\mathrm{S})$ & G1 & 11 & 24 & 7 & 1(all R):2[3(R+LS):1S]:1(all S) & 1.62 & 0.45 \\
\hline PI $88788(\mathrm{R}) \times$ Essex $(\mathrm{S})$ & G7 & 11 & 24 & 7 & $1($ all R $): 2(3 \mathrm{R}: 1 \mathrm{~S}): 1($ all $S)$ & 1.62 & 0.45 \\
\hline PI $88788(\mathrm{R}) \times$ Lee $68(\mathrm{~S})$ & G1 & 8 & 17 & 10 & 1(all R):2[3(R+LS):1S]:1(all S) & 0.26 & 0.88 \\
\hline PI $88788(\mathrm{R}) \times \mathrm{V} 94-5152(R s v 4)$ & G1 & 46 & 0 & 0 & $\ldots$ & $\ldots$ & $\ldots$ \\
\hline
\end{tabular}

a $\mathrm{R}$, resistant; H, segregating; $\mathrm{S}$, susceptible.

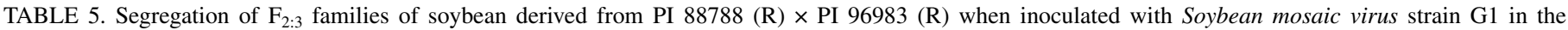
greenhouse

\begin{tabular}{|c|c|c|c|c|c|}
\hline \multirow[b]{2}{*}{ Reaction $^{\mathrm{a}}$} & \multirow[b]{2}{*}{ Frequency } & \multicolumn{2}{|c|}{ Number of families } & \multirow[b]{2}{*}{$\chi^{2} 7: 4: 4: 1$} & \multirow[b]{2}{*}{$P$} \\
\hline & & Observed & Expected & & \\
\hline All R & 7 & 28 & 22.75 & $\ldots$ & $\ldots$ \\
\hline $3(\mathrm{R}+\mathrm{N}+\mathrm{LS}): 1 \mathrm{~S}$ & 4 & 12 & 13 & $\ldots$ & $\ldots$ \\
\hline $15(\mathrm{R}+\mathrm{N}+\mathrm{LS}): 1 \mathrm{~S}$ & 4 & 9 & 13 & $\ldots$ & $\ldots$ \\
\hline All S & 1 & 3 & 3.25 & $\ldots$ & $\ldots$ \\
\hline Total & 16 & 52 & 52 & 2.54 & 0.47 \\
\hline
\end{tabular}

a $\mathrm{R}$, resistant (symptomless); N, stem tip necrosis; S, susceptible; LS, late susceptible. 
deficiency of LS plants and excess of R plants. Affecting factors in this case could be the age of the plants at inoculation, the inoculation procedure, or different environmental conditions. In the greenhouse, plants were inoculated at 10 days after planting (V1 stage), whereas field-grown plants were inoculated 3 to 4 weeks after planting (V2 to V3 stage). In the greenhouse, both unifoliolate leaves were inoculated by rubbing evenly with a pestle dipped in inoculum. In the field, an artist's airbrush, which is more damaging to plant tissue, was used to inoculate only one leaflet of the first or second trifoliolate leaf on each plant, using sufficient pressure and proximity to cause water-soaking of cells. The larger area of the unifoliolate leaves inoculated with SMV by pestle inoculation in the greenhouse, with minimal wounding of the inoculated cells, presumably increased the probability of establishing an infection site and leading eventually to LS symptoms. Reduced infection could have been an inoculum dosage effect, but more likely it is the result of the damage caused by air brush inoculation and cell death prior to virus movement from initially inoculated cells.

Following inoculation with SMV-G7, LS was not observed in $\mathrm{F}_{1}$ plants, $\mathrm{F}_{2}$ populations, and $\mathrm{F}_{2: 3}$ families of PI $88788 \times$ Essex and PI $88788 \times$ Lee 68, indicating that the Rsv4 gene is completely dominant to this pathotype. Although our data show some variation in response to the two pathotypes, it is clear that the same gene controls the resistance to SMV strains G1 and G7 in PI 88788 because all $\mathrm{F}_{2: 3}$ families of PI $88788 \times$ Essex populations exhibited the same reaction to both SMV strains G1 and G7.

Partial dominance implies that resistance is expressed more effectively in the homozygous (RR) than heterozygous ( $R r)$ state. This is observed in Rsvl as complete resistance with homozygotes and systemic necrosis with heterozygotes $(10,18)$. However, local and systemic necrosis also may be observed when a homozygous resistance gene at the $R s v l$ locus interacts with specific SMV strains (10). For example, Rsvl from PI 96983 develops systemic necrosis when inoculated with SMV-G7 (9) and Rsv3 derived from Columbia responds to SMV-G1 with a necrotic reaction (7). These observations suggest that $R s v 1$ and $R s v 3$ possess receptor domains that bind viral elicitors to activate a hypersensitive defense response, consistent with the observation that these genes map to resistance gene clusters $(20,23)$.

Resistance to SMV in PI 88788 is, thus, a unique type of resistance within the SMV-soybean pathosystem because it does not appear to utilize well-characterized defense pathways. No hypersensitive response was observed in plants having the Rsv4 gene in either a homozygous or heterozygous state following inoculation with any SMV strain. Resistance results from a restriction in cellto-cell and vascular movement of the virus in the inoculated leaves, based on SMV-G1 and -G7 data. The LS phenotype is described that is detected only in heterozygous plants observed over a longer period of time. In this response, early restriction to virus movement by the gene was overcome, perhaps by virus-mediated suppression of gene silencing, enabling the virus to move through the vascular system and invade newly developing leaves. Movement within these leaves, however, also is restricted resulting in veinal chlorosis and green islands exhibited in the LS phenotype.

TABLE 6. Segregation of $\mathrm{F}_{2: 3}$ families of soybean derived from L29(R) $\times$ PI 88788 (R) when inoculated with Soybean mosaic virus strain G7 in the greenhouse

\begin{tabular}{|c|c|c|c|c|c|}
\hline \multirow[b]{2}{*}{ Reaction $^{\mathrm{a}}$} & \multirow[b]{2}{*}{ Frequency } & \multicolumn{2}{|c|}{ Number of families } & \multirow[b]{2}{*}{$\chi^{2} 7: 4: 4: 1$} & \multirow[b]{2}{*}{$P$} \\
\hline & & Observed & Expected & & \\
\hline All R & 7 & 23 & 20.56 & $\ldots$ & $\ldots$ \\
\hline $3(\mathrm{R}): 1 \mathrm{~S}$ & 4 & 12 & 11.75 & $\ldots$ & $\ldots$ \\
\hline $15(\mathrm{R}): 1 \mathrm{~S}$ & 4 & 8 & 11.75 & $\ldots$ & $\ldots$ \\
\hline All S & 1 & 4 & 2.94 & $\ldots$ & $\ldots$ \\
\hline Total & 16 & 47 & 47 & 1.88 & 0.60 \\
\hline
\end{tabular}

a R, resistant (symptomless); LS, late susceptible; S, susceptible.
The Rsv4 gene in PI 88788 appears to be the first report of a single dominant gene that confers resistance by interfering with viral movement. Resistance to potyviruses occurs in a number of major crop species, with a range of resistance mechanisms. Single dominant genes, such as Rsvl and Rsv3 in soybean, have been shown in most cases to condition extreme resistance or hypersensitive resistance responses. Other examples include $R y_{\text {sto }}$, conferring resistance in potato to potyviruses Tobacco etch virus (TEV) and Potato virus $Y$ (PVY) (22), and the $N v$ gene in potato (2) conferring broad-spectrum resistance to several potyviruses. Resistance of Arabidopsis thaliana to TEV, however, is conditioned by two dominant, phloem functioning, genes RTM1 and RTM2, which cooperate to restrict long-distance movement of the virus (12). A similar mechanism has been postulated for one resistance phenotype of $A$. thaliana to another potyvirus, Lettuce mosaic virus (30). However, neither of these reports recognizes an LS phenotype. The resistance conditioned by recessive genes often has been associated with a mechanism involving restriction to virus accumulation and viral movement. This type of resistance has been described for several potyviruses, including the recessive genes for resistance to Zucchini yellow mosaic virus and other potyviruses in cucurbits (35), PVY in pepper (1), Potato virus $A$ in potato (19), and PVY and TEV in tobacco $(26,31)$. Additionally, dominantly inherited quality trait loci mapping to seven genomic regions have been associated with resistance of pepper to Cucumber mosaic virus (genus Cucumovirus, family Bromoviridae) by a mechanism involving partial restriction to long-distance movement (8).

Deployment of cultivars possessing Rsv4 may contribute to broad, effective, and long-term resistance. The gene allows limited accumulation of virus, prevents rapid long-distance movement of virus, and delays symptom expression. Of the SMV strains tested, none were found to overcome resistance at $R s v 4$, in contrast to the $R s v 1$ and $R s v 3$ loci which are overcome by several strains (Table 1). Strategies for managing SMV disease can include reducing the initial inoculum to a low level, reducing the temporal virus progress (such as utilizing $R s v 4$ and managing virus vectors), and reducing the time span that host-pathogen populations interact (27). Thus, for SMV and related viruses, host resistance that reduces the initial success of establishing infection and rate of within-plant spread may provide benefits in terms of efficacy and durability $(3,27,28)$. Benefits of reduction in incidence and delay in symptom appearance also have been demonstrated with transgenic resistance to SMV in soybean (34). Because Rsv4 exhibits this mode of action as well as broad resistance to SMV strains, it should be a valuable gene to deploy in new cultivars or to pyramid with other $R$ genes.

\section{ACKNOWLEDGMENTS}

This work was supported in part by funding from the Virginia Agricultural Experiment Station and the Virginia Soybean Board. We thank M. Baldwin for technical assistance with immunoassays and virus strain maintenance.

\section{LITERATURE CITED}

1. Arryo, R., Soto, M. J., Martinez-Zapater, J. M., and Ponz, F. 1996. Impaired cell-to-cell movement of potato virus $\mathrm{Y}$ in pepper plants carrying the $y^{\mathrm{a}}\left(p r 2^{\mathrm{I}}\right)$ resistance gene. Mol. Plant-Microbe Interact. 9:314-319.

2. Barker, H. 1997. Extreme resistance to potato virus V in clones of Solanum tuberosum that are also resistant to potato viruses $\mathrm{Y}$ and $\mathrm{A}$ : Evidence for a locus conferring broad-spectrum potyvirus resistance. Theor. Appl. Genet. 95:1258-1262.

3. Bar-Zur, A., and Salomon, R. 1995. Partial resistance of sugary enhancer sweet corn genotypes to two isolates of sugarcane mosaic subgroup of potyviruses. Plant Dis. 79:243-246.

4. Buss, G. R., Ma, G., Chen, P., and Tolin, S. A. 1997. Registration of V945152 soybean germplasm resistant to soybean mosaic potyvirus. Crop Sci. 37:1987-1988. 
5. Buss, G. R., Ma, G., Kristipati, S., Chen, P., and Tolin, S. A. 1999. A new allele at the Rsv3 locus for resistance to soybean mosaic virus. Page 490 in: Proc. World Soybean Res. Conf. VI. H. E. Kaufman, ed. Chicago.

6. Buzzell, R. I., and Tu, J. C. 1984. Inheritance of soybean resistance to soybean mosaic virus. J. Hered. 75:82.

7. Buzzell, R. I., and Tu, J. C. 1989. Inheritance of a soybean stem-tip necrosis reaction to soybean mosaic virus. J. Hered. 80:400-401.

8. Caranta, C., Pflieger, S., Lefebvre, V., Daubeze, A. M., Thabuis, A., and Palloix, A. 2002. QTLs involved in the restriction of cucumber mosaic virus (CMV) long-distance movement in pepper. Theor. Appl. Genet. 104:586-591.

9. Chen, P., Buss, G. R., Roane, C. W., and. Tolin, S. A. 1991. Allelism among genes for resistance to soybean mosaic virus in strain differential soybean cultivars. Crop Sci. 31:305-309.

10. Chen, P., Buss, G. R., Roane, C. W., and Tolin, S. A. 1994. Inheritance in soybean of resistance and necrotic reactions to soybean mosaic virus strains. Crop Sci. 31:414-422.

11. Chen. P., Ma, G., Buss, G. R., Gunduz, I., Roane, C. W., and Tolin, S. A. 2001. Inheritance and allelism test of Raiden soybean for resistance to soybean mosaic virus. J. Hered. 92:51-55.

12. Chisholm, S. T., Parra, M. A., Anderberg, R. J., and Carrington, J. C. 2001. Arabidopsis RTM1 and RTM2 genes function in phloem to restrict longdistance movement of tobacco etch virus. Plant Physiol. 127:1667-1675.

13. Cho, E. K., Chung, B. J., and. Lee, S. H. 1977. Studies of identification and classification of soybean virus diseases in Korea. II. Etiology of necrotic disease of Glycine max. Plant Dis. Rep. 61:313-317.

14. Cho, E. K., and Goodman, R. M. 1979. Strains of soybean mosaic virus: classification based on virulence in resistant soybean cultivars. Phytopathology 69:467-470.

15. Cho, E. K., and Goodman, R. M. 1982. Evaluation of resistance in soybeans to soybean mosaic virus strains. Crop Sci. 22:1133-1136.

16. Gera, T., and Tolin, S. A. 1994. Tracking soybean mosaic virus movement by immunoassay of leaf imprints. (Abstr.) Phytopathology 84:544.

17. Gunduz, I., Buss, G. R., Ma, G., Chen, P., and Tolin, S. A. 2001. Genetic analysis of resistance to soybean mosaic virus in OX670 and Harosoy soybean. Crop Sci. 41:1785-1791.

18. Kiihl, R. A. S., and Hartwig, E. E. 1979. Inheritance of reaction to soybean mosaic virus in soybeans. Crop Sci. 20:403-404.

19. Hamalainen, J. H., Kekarainen, T., Gebhardt, C., Watanabe, K. N., and Valkonen, J. P. T. 2000. Recessive and dominant genes interfere with the vascular transport of potato virus A in diploid potatoes. Mol. PlantMicrobe Interact. 13:402-412.

20. Hayes, A. J., Ma, G., Buss, G. R., and Saghai-Maroof, M. A. 2000. Molecular marker mapping of $R s v 4$, a gene conferring resistance to all known strains of soybean mosaic virus. Crop Sci. 40:1434-1437.

21. Hill, J. H. 1999. Soybean mosaic. Pages 70-71 in: Compendium of Soybean Diseases. 4th ed. G. L. Hartman, J. B. Sinclair, and J. C. Rupe, eds. The American Phytopathological Society, St. Paul, MN.

22. Hinrichs, J., Berger, S., and Shaw, J. G. 1998. A hypersensitive response like mechanism is involved in resistance of potato plants bearing the $R y_{\text {sto }}$ gene to the potyviruses potato virus $\mathrm{Y}$ and tobacco etch virus. J. Gen. Virol. 79:167-176.

23. Jeong, S. C., Kristipati, S., Hayes, A. J., Maughan, P. J., Noffsinger, S. L., Gunduz, I., Buss, G. R., and Saghai Maroof, M. A. 2002. Genetic and sequence analysis of markers tightly linked to the soybean mosaic virus resistance gene, Rsv3. Crop Sci. 42:265-270.

24. Ma, G., Chen, P., Buss, G. R., and Tolin, S. A. 1995. Genetic characteristics of two genes for resistance to soybean mosaic virus in PI 486355 soybean. Theor. Appl. Genet. 91:907-914.

25. Ma, G., Chen, P., Buss, G. R., and Tolin, S. A. 2002. Complementary action of two independent dominant genes in Columbia soybean for resistance to Soybean mosaic virus. J. Hered. 93:179-184.

26. Matsuta, C., Mishimura, M., Morishita, H., and Hataya, T. 1999. A single amino acid change in viral genome-associated protein of potato virus $Y$ correlates with resistance breaking in Virgin A mutant tobacco. Phytopathology 89:118-123

27. Nutter, F. W., Jr., Schultz, P. M., and Hill, J. H. 1998. Quantification of within field spread of soybean mosaic virus in soybean using strainspecific monoclonal antibodies. Phytopathology 88:895-901.

28. Padgett, G .B., Nutter, F. W., Jr., Kuhn, C. W., and All, J. N. 1990. Quantification of disease resistance that reduces the rate of tobacco etch virus epidemic in bell pepper. Phytopathology 80:451-455.

29. Rao-Arelli, A. P., Anand, S. C., and Wrather, J. A. 1988. Soybean resistance to soybean cyst nematode race 3 is conditioned by an additional dominant gene. Crop Sci. 32:862-864

30. Revers, F., Guiraud, T., Houvenaghel, M.-C., Mauduit, T., le Gall, O., and Candresse, T. 2003. Multiple resistance phenotypes to Lettuce mosaic virus among Arabidopsis thaliana accessions. Mol. Plant-Microbe Interact. 16:608-616.

31. Schaad, M. C., and Carrington, J. C. 1996. Suppression of long-distance movement of tobacco etch virus in a nonsusceptible host. J. Virol. $71: 2556-2561$

32. Shipe, E. R., Buss, G. R., and Tolin, S. A. 1979. A second gene for resistance to peanut mottle virus in soybeans. Crop Sci. 19:656-658.

33. Srinivasan, I., and Tolin, S. A. 1992. Detection of three viruses of clovers by direct tissue immunoblotting. (Abstr.) Phytopathology 82:721.

34. Steinlage, T. A., Hill, H. H., and Nutter, F. W., Jr. 2002. Temporal and spatial spread of Soybean mosaic virus (SMV) in soybeans transformed with the coat protein gene of SMV. Phytopathology 92:478-486.

35. Ullah, Z., and Grumet, R. 2002. Localization of Zucchini yellow mosaic virus to the veinal regions and the role of viral coat protein in veinal chlorosis conditioned by the zym potyvirus resistance locus in cucumber. Physiol. Mol. Plant Pathol. 60:79-89.

36. Yu, Y. G., Buss, G. R., and Saghai-Maroof, M. A. 1996. Isolation of a superfamily of candidate disease-resistance genes in soybean based on a conserved nucleotide-binding site. Proc. Natl. Acad. Sci. USA 93:1175111756

37. Yu, Y. G., Saghai Maroof, M. A., Buss, G. R., Maughan, P. J., and Tolin, S. A. 1994. RFLP and microsatellite mapping of a gene for soybean mosaic virus resistance. Phytopathology 84:60-64. 